\title{
Phytochemical, Antinutrient and Amino Acid Composition of Synsepalum dulcificum Pulp
}

\author{
${ }^{1}$ Nkwocha Chinelo C., ${ }^{2}$ Njoku Obi U. and ${ }^{3}$ Ekwueme Florence N. \\ ${ }^{1,2,3}$ Department of Biochemistry, University of Nigeria, Nsukka, Enugu State, Nigeria.
}

\begin{abstract}
Quantitative phytochemical test shows that the pulp contains 3.45\% saponin, $57.01 \%$ flavonoids, $7.12 \%$ tannin, $0.0001 \%$ alkaloids, $0.0001 \%$ glycosides, $0.0003 \%$ resins, $0.0002 \%$ terpenoids, $0.0001 \%$ steroids and $0.0003 \%$ cyanogenic glycosides.Antinutrient analyses of the pulp show $5.67 \%$ oxalate, $0.03 \%$ phytates and $0.02 \%$ hemagglutanin. Amino acid analyses shows that S.dulcificum pulp contains $8.055 \%$ tryptophan, $1.35 \%$ phenylalanine, $0.7 \%$ isoleucine, $0.5 \%$ tyrosine, $1.05 \%$ methionine, $0.4 \%$ proline, $0.69 \%$ valine, $1.1 \%$ threonine, $0.4 \%$ histidine, $0.5 \%$ alanine, $1.02 \%$ glutamine, $1.6 \%$ glutamic acid, $0.7 \%$ glycine, $0.3 \%$ serine, $1 \%$ arginine, $0.1 \%$ aspartic acid, $1.23 \%$ asparagine, $0.6 \%$ lysine and $0.6 \%$ leucine.
\end{abstract}

Keywords: synsepalum dulcificum, phytochemical, amino acid, antinutrient

\section{Introduction}

Synsepalum dulcificum is known variously as miracle fruit, magic fruit, miraculous or flavour fruit (Duke and Ducellier, 1993). It is a shrub that grows up to 20ft $(6.1 \mathrm{~m})$ high in its native habitat but does not usually grow higher than $10 \mathrm{feet}$ in cultivation(Wiersema and Leon,1999). Its leaves are $5-10 \mathrm{~cm}$ long, $2-3.7 \mathrm{~cm}$ wide and glabrous below and are clustered at the end of the branchlets. The shrub carries orange coloured fruits with each containing one seed (Duke and Ducellier, 1993). The seeds are about the size of coffee beans. The fruit has been used in West Africa since the $18^{\text {th }}$ century, when explorer from Europe namely Chevalier des Marchais was searching for different fruits native to West Africa (Roecklein and Leung,1987). The fruit has a low sugar content and contains a glycoprotein molecule called miraculin (Forester and Waterhouse, 2009). When the fleshy part of the fruit is eaten, the glycoprotein binds to the tongue's taste bud causing sour foods to taste sweet. While the exact cause for this change is unknown, it is believed that the glycoprotein, miraculin works by distorting the sweet receptors so that they become responsive to acids, instead of sugar and other sweet things (Hirai et al., 2006). This effect lasts 10min-2hours (Joseph et al., 2009). Preliminary studies on the leaves of the plant show that the leaves are very rich source of phytosterol (Chen et al., 2010). In Africa, S.dulcificum leaves are attacked by lepidopterous larvae and the fruits are infested with the larvae of fruit flies (Peter, 2001). A fungus which has been found on this plant is microporus(Duke and Ducellier, 1993). In tropical West Africa where this specie originates, the fruit pulp is used to sweeten palm wine (Joseph et al., 2009). There is really no information on this fruit as regards its nutritive and antinutritive composition. This study is therefore aimed at finding out the phytochemical and antinutrient composition of synsepalum dulcificum pulp as well as the amino acid composition for public awareness of its nutritional status.

\section{Sample Collection and Preparation}

\section{Materials And Methods}

Samples of the fruit of S.dulcificum (miracle fruit) were collected from Uke in Anambra State, Nigeria. The plant material obtained was identified by Mr. Alfred Ozioko, the botanist at Bioresource and Development Conservative Programme (BDCP), Nsukka, Enugu State, Nigeria. The fruit was cleaned and washed; the pulp removed from the fruit and was extracted with methanol. Quantitative phytochemical tests of the pulp of S.dulcificum for the relative abundance or absence of alkaloids, glycosides, saponins, flavonoids, tannins, cyanide, resins, terpenoid and steroids were carried out by methods described by Pearson (1976). Antinutrient contents (oxalates, phytates and haemaglutanin) of fruit pulp were determined by methods described by the Association of Official and Analytical Chemists (AOAC, 1990).Amino acid determination of the fruit pulp was determined using an amino acid analyzer.

\section{Results And Discussion}

The quantitative phytochemical composition of S. dulcificum pulp as observed in Table 1 shows a relatively high concentration of flavonoids while bioactive compounds like tannin and saponin were present in small concentrations. Flavonoid isolated from eggplant peel is a potent antioxidant and free radical scavenger and has been shown to protect cell membranes from damage (Noda et al., 2000). Flavonoids extracted from the fruits of $S$. melongena showed significant hypolipidemic action in normal and cholesterol fed rats (Sudheeshet al., 1997). In vitro studies have also shown that flavonoids have anti-allergic, anti-inflammatory, 
anti-microbial and anti-cancer activities (Cushnie and Lamb, 2005; Sousa et al., 2007; Yamamoto and Gaynor, 2001). Tannins have astringent properties that affect palatability, reduce food intake and consequently body growth. It also hastens the healing of wounds and prevention of decay. Tannin compounds have antimicrobial activities and are responsible for preventing and treating urinary tract infections and other bacterial infections. They are known to inhibit the activities of digestive enzymes and nutritional effects of tannins are mainly related to their interaction with protein. Tannin protein complexes are insoluble and the protein digestibility is decreased (Carnovale et al., 1991). Studies on rats, chicks and livestock revealed that high tannin in the diet adversely affect digestibility of proteins and carbohydrates thereby reducing growth, feeding efficiency, metabolizable energy and bioavailability of amino acids (Aletor, 1993). From medicinal point of view, polyphenol to which tannin belongs has been reported to act as antioxidant by preventing oxidative stress that causes diseases such as coronary heart diseases, some types of cancers and inflammation (Tapiero et al., 2002)).This shows that $S$. dulcificum pulp is likely to have antioxidant activity. Saponins are known to reduce certain nutrients like glucose and cholesterols at the gut through intra-lumenal physicochemical interaction (Price et al., 1987). Also, when saponins are consumed they may aid in lessening the metabolic burden that would have been placed on the liver (Igboh et al., 2009). They are known to inhibit the structure dependent biological activities (Savage, 1993). Saponins have been reported to be useful in reducing inflammation of upper respiratory passage and also chiefly as foaming and emulsifying agents and detergents (Frantisek, 1991).These compounds serve as natural antibiotics, helping the body to fight infections and microbial invasion (Okwu, 2004). Phytochemicals like alkaloids, glycosides, resins, terpenoids, steroids and cyanogenic glycosides were present in trace concentrations as shown in Table 1. Alkaloids, saponins and tannins are known to have antimicrobial activities as well as other physiological activities (Sofowora, 1993; Evans, 2005). Alkaloids are known for their toxicity but not all alkaloids are toxic. Alkaloids inhibit certain mammalian enzymatic activities such as those of phosphodiesterase, prolonging the action of cAMP. They also affect glucagons and thyroid stimulating hormones, while some forms have been reported to be carcinogenic (Okaka et al., 1992). Some have been used either as an analgesic, antispasmodic or bactericidal agents (Frantisek, 1991).Resins which were present in the pulp are important because they can be used in African medicine (Leakey, 1999).The resins are medicinal and are applied to cure skin diseases such as ringworms, craw-craw and jiggars (Hutchinson et al., 1993). Resins when applied in lotions and creams stabilize emulsion, add smoothness to the skin and form protective coating on the skin. The presence of steroids indicates the cholesterol lowering potential of the pulp which may likely be of great benefit in the prevention and treatment of atherosclerosis and heart disease. The results obtained from the phytochemical test indicates that the pulp possess some biologically active compounds which could serve as potential source of vegetable drugs in herbal medicine. These phytochemical exhibit diverse pharmacological and biochemical actions when ingested by animals (Amadi et al., 2006).

Amino acids is a class of biologically active compounds present in food and beverages and are important for human nutrition (Massey et al., 1998) and affect the quality of foods including taste, aroma, and color (Ames, 1998; Haefeli and Glaser, 1990). Amino acids are useful markers to define fruit juice genuineness; however, their use is complicated by the natural variability of fruit compositions (Linskens et al., 1988).

Figure 1 shows that S.dulcificum pulp contains $8.055 \%$ tryptophan, $1.35 \%$ phenylalanine, $0.7 \%$ isoleucine, $0.5 \%$ tyrosine, $1.05 \%$ methionine, $0.4 \%$ proline, $0.69 \%$ valine, $1.1 \%$ threonine, $0.4 \%$ histidine, $0.5 \%$ alanine, $1.02 \%$ glutamine, $1.6 \%$ glutamic acid, $0.7 \%$ glycine, $0.3 \%$ serine, $1 \%$ arginine, $0.1 \%$ aspartic acid, $1.23 \%$ asparagine, $0.6 \%$ lysine, $0.6 \%$ and leucine. A study of the amino acid distribution shows that the pulp contains both the essential and non- essential amino acids in high concentrations. Such rich contents for these amino acids make it irreplaceable as a raw material for the production of pharmaceuticals and diet supplements. Particular focus is given to the lysine requirements of adults, since this indispensable amino acid is most likely to be limiting in the cereal-based diets characteristic of populations in large areas of the developing world (Young and Pellett, 1990; Hoshiai, 1995).For some amino acids, considerable literature exists from human and animal studies; in particular, glutamate, aspartate, and phenylalanine are well represented because of their use as food-flavoring agents (glutamate as monosodium gluatamate (MSG) and aspartate and phenylalanine in aspartame) and lysine for some treatment effects (Garlick, 2004). Considerably higher level of phenylalanine compared to daily intake was obtained in this study. Concern for the safety of phenylalanine arises from the abnormal brain development known to occur in humans with phenylketonuria. But, in those with a normal ability to metabolize phenylalanine, this amino acid is relatively safe. Investigated essential amino acids, the building blocks of all proteins in the body and some hormones are termed indispensable amino acids which must be provided in the diet. In this study, sufficient amount of essential amino acids expressing valuable nutritious potential of this fruit were obtained. Although no single plant would provide humans with adequate levels of all essential amino acids, S.dulcificum pulp can be consumed with other foods and contribute useful amounts of the amino acids to the diet.

The antinutrient composition of S.dulcificum pulp presented in Table 2 shows that $S$. dulcificum pulp contains $5.67 \%$ oxalates, $0.03 \%$ phytates and $0.02 \%$ hemagglutanin. The oxalate value is higher than 
$1.06 \mathrm{mg} / 100 \mathrm{~g}$ reported for B.coricea seeds (Amaechi, 2009) and $0.159 \mathrm{mg} / 100 \mathrm{~g}$ reported for Pennsetum purpureum (Okaraonye and Ikewuchi, 2009) but lower than $(58.81 \mathrm{mg} / 100 \mathrm{~g}$ ) reported for seeds of Solanum nigrum (Akubugwo et al., 2007) and 109.00mg/100g reported for Gnetum africanum seeds (Ekpo,2007).Oxalate is of concern because of its negative effect on mineral availability. High oxalate diet can increase the risk of renal calcium absorption and has been implicated as a source of kidney stones (Chai and Liebman, 2004). The level of oxalate in the fruit may not play important role in its nutritive value. Munro and Bassir (1989) have revealed that the possibility of oxalate poisoning in Nigeria from consumption of local fruit and vegetables is as remote as it is in other parts of the world.

The phytate content of S. dulcificum pulp is lower than $0.006 \%$ reported for Pennsetum purpureum (Okaraonye and Ikewuchi, 2009) and $0.318 \mathrm{mg} / 100 \mathrm{~g}$ reported for B.coricea seeds (Amaechi, 2009). The knowledge of phytate level in foods is necessary because high concentration of phytate can cause adverse effect on digestibility. Also, phytic acid binds metals like calcium, zinc, iron and other minerals thereby reducing their bioavailability in the body (FAO, 1990).Similarly, phytic acid binds to phosphorus and converts it to phytate which is an indigestible substance thereby decreasing the bioavailability of this element for consumption They also inhibit digestion of proteins by forming complexes with them (Singh and Krikoran, 1982). Phytic acid have a negative effect on amino acid digestibility, thereby posing problem to non-ruminant animals due to insufficient amount of intrinsic phytase necessary to hydrolyse the phytic acid complex, but the presence is also beneficial because it may have a positive nutritional role as an antioxidant and anti-cancer agent.

Table 1: Phytochemical Composition of S. dulcificum pulp

\begin{tabular}{|l|l|}
\hline PHYTOCHEMICALS & QUANTITY \\
\hline Flavonoids & $57.01 \%$ \\
Tannins & $7.12 \%$ \\
Saponins & $3.45 \%$ \\
Alkaloids & $0.0001 \%$ \\
Glycosides & $0.0001 \%$ \\
Resins & $0.0003 \%$ \\
\hline
\end{tabular}

Figure 1: Amino Acid composition of S.dulcificum pulp

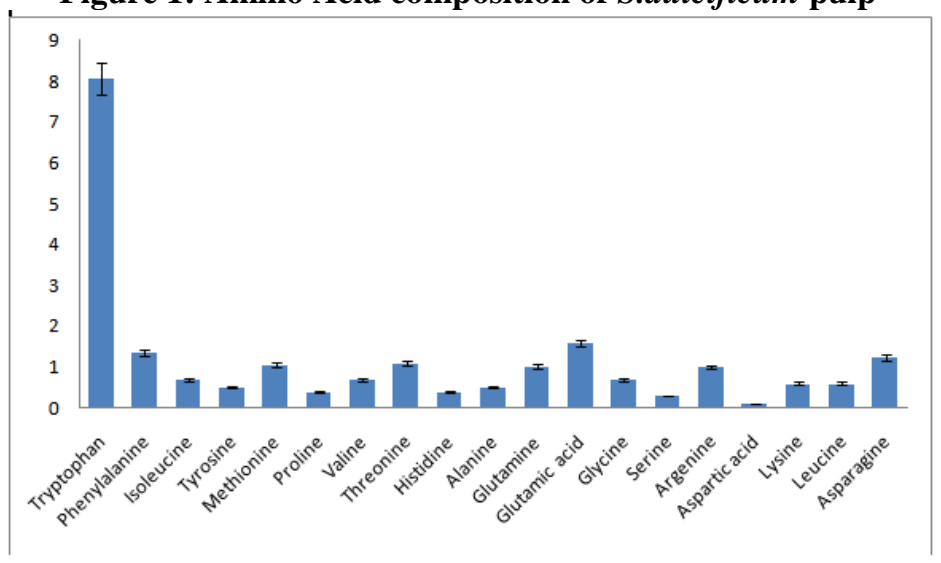

Table 2: Antinutrient composition of S.dulcificum pulp

\begin{tabular}{|ll|}
\hline ANTINUTRIENTS & CONCENTRATION (\%) \\
\hline Oxalates & 5.67 \\
\hline Phytates & 0.03 \\
\hline Haemagglutanin & 0.02 \\
\hline
\end{tabular}




\section{Acknowledgement}

I sincerely acknowledge the effort of Nwodo, O.F.C. and Joshua, P.E. towards the successful completion of this work. I remain ever garateful.

\section{References}

[1]. Akubugwo, I.E., Obasi, A.N. and Ginika, S. (2007). Nutritional Potentials of leaves and seeds of Black Nightshade Solanum nigrum L Var virginicum from Afikpo, Nigeria. Pakistan Journal of Nutrition, 6:323-326.

[2]. Aletor, V.A. (1993). Allelo chemicals in plant food and feeding stuffs (I). Nutritional, Biochemical and Psychopathological aspects in animal production. J. Vet.Hum. Toxicol, 35(1):57-67.

[3]. Amadi, B.A., Ibegbulem, C.O. and Egbebu, A.C. (2006). Assessment of the effect of aqueous extract of (Asimina triloba) root on organ weights and liver functions of albino rats. Int. J. Nat. Appl. Sci., 2:79-81.

[4]. Amaechi, N.C. (2009). Nutritive and anti-nutritive evaluation of Wonder kola (Buccholzia coricea) seeds. Pakistan Journal of Nutrition, $8(8): 1120-1122$

[5]. Ames, J.M. (1998). Application of the mailand reaction in the food industry. Food Chem, 62:431-439.

[6]. Association of Official Analytical Chemists (AOAC) (1990). Official methods of analysis. $15^{\text {th }}$ Ed.,Washington, D.C. Pp 220 - 224

[7]. Carnavole, E., Lugaro, E. and Marconi, E. (1991). Protein quality and antinutritional factors in wild and cultivated species of vigna spp. Plant Food Hum. Nutr., 41(1): 11-20.

[8]. Chen C.Y, Wang Y.D. and Wang H.M. (2010).Chemical constituents of the leaf.Chemical Journal of Natural Compouds.46:495

[9]. Duke, J.A. and Ducellier, J.L. (1993).Handbook of Alternative Cash Crops.CRC Press. pp. 433-434.

[10]. Cushnie, T.P. and Lamb, A.J. (2005). Review: Antimicrobial activity of flavonoids. International Journal of Antimicrobial Agents, 26: 343-356.

[11]. Chai, W. and Liebman, M.(2004). Assessment of oxalate absorption from almonds and black beans with and without the use of an extrinsic label. J. Uro., 172:953-957.

[12]. Ekpo, A.S. (2007). Determination of chemical composition of Gnetun africanum (Afang) seeds. Pakistan Journal of Nutrition, 6:4043.

[13]. Evans, N.S. (2005). Trease and Evans.Pharmacognosy. $15^{\text {th }}$ Edn, Elsevier, India. pp 1-24.

[14]. FAO (1990). Root, Tuber, Plantains and Bananas in Human Nutrition. FAO Corporate Document Repository, Rome. $\mathrm{http} / /$ www.fao.org/docrep/t0207e

[15]. Forester, S.C.and Waterhouse, A.L.(2009). Metabolites are key to understanding health effects of wine polyphenolics. JournalofNutrition, 139:1824-1831.

[16]. Hirai, T., Fukukawa, G.,Kakuta, H., Fukuda, N. and Ezulura, H. (2009)."Production of recombinant miraculin using transgenic tomatoes in a closed cultivation system".Journal of Agriculture and Food Chemistry., 58:10.

[17]. Frantisek, S.S. (1991). The Natural Guide to Medicinal Herbs and Plants. Tiger Barks Cast, Twinkemhan, United Kingdom. pp.1-5.

[18]. Garlick, P.J. (2004). The nature of human hazards associated with excessive intake of amino acids. Journal of Nutrition, 134: 16331639.

[19]. Haefeli, R.J. and Glasor, D. (1990). Taste responses and thresholds obtained with the primary amino acids in humans. LebensmWiss U-Technol, 23:523- 527.

[20]. Hoshiai, K.(1995). World balance of dietary essential amino acids relative to the 1989 FAP/WHO protein scoring pattern. Food Nutrition Bulletin, 16:166-177.

[21]. Hutchinson, J. M., Dalziel, J. and Hepper, F. N. (1993). Flora of West Africa (Vol. 11) Macmillan Publishers Ltd, Lagos. pp. 252 260.

[22]. Igboh, M.N., Ikewuchi, C.J. and Ikewuchi, C.C. (2009). Chemical profile of chormolaena odoratal. Pakistan Journal of Nutrition, 8(5):521-524.

[23]. Joseph, J.A.,Shukitt-Hale, B.,Willis,L.M.(2009). Grape juice, berries and walnuts affect brain aging and behavior. JournalofNutrition, 139:1818-1823.

[24]. Leakey, R. R. B. (1999). Potential for Novel Food Products from Agro Forestry Trees. A Review of Food Chemistry, $1-4$

[25]. Linskens, H.F., Jackson, J.F. and Fang, T.T. (1988). Modern Methods of Plant Analysis. Springer-Verlag Berlin, Germany. pp. 5168.

[26]. Massey, K.A., Blakeslee, C.H. and Pitlow, H.S. (1998). A review of physiological and metabolic effects of essential amino acids. Amino acids, 14: 271- 300.

[27]. Munro, A. and Basir, O. (1969). Oxalate in Nigerian vegetables. West African Journal of Biology and Applied Chemistry, 12(1):418.

[28]. Noda, Y., Kneyuki, T., Igarashi, K., Mori, A. and Packer, L. (2000). Antioxidant activity of nasunin, an anthocyanin in egg plant peels. Toxicology, 148:119-123

[29]. Okaka, J.C., Enoch, N.J. and Okaka, N.C. (1992). Human Nutrition: An Integrated Approach. Enugu, ESUT Publications. Pp. $57-$ 58.

[30]. Okaraonye, C.C. and Ikewuchi, J.C. (2009). Nutrition and Anti-nutritional Components of Pennisetum ipnpureum Schmach. Pakistan Journal of Nutrition8:32-34.

[31]. Okwu, D. E. (2004). Phytochemicals and Vitamin content of Indigenous Spices of South Eastern Nigeria. Journal of Sustainable Agriculture Environment6(1):30 - 37.

[32]. Peter, H. (2001). Mansfeld's Encyclopedia of Agricultural and Horticultural crops, 2.Springer.pp.1660.

[33]. Price, K.R., Johnson, L.I. and Feriwick, H. (1987). The chemical and biological significance of saponins in foods and feeding stuffs. Critical Reviews in Food Science and Nutrition, 26:127-135.

[34]. Roecklin, J.C. and Leung, P. (1987). A Profile of Economic Plants. Transaction Publishers. pp. 412.

[35]. Savage, G.P. (1993). Saponins. In: Encyclopaedia of Food Science, Food Technology and Nutrition, Macrae, R., Robinson, R.K. and Sadler, M.J. (Eds). Academic Press London. pp. 3998-4001.

[36]. Singh, M. and Krikoran, A.D. (1982). Inhibition of trypsin activity in vitro by phytate. Journal of Agric and Food Chemistry,30: 799-800.

[37]. Sofowora, E.A. (1993). Medicinal Plants and Traditional Medicine in Africa. Ibadan-Owerri-Kaduna-Lagos Spectrum Books Limited. pp 159-176; 179-189; 195-238.

[38]. Sousa, R.R., Queiroz, K.C., Souza, A.C., Gurgueira, S.A., Augusto, A.C., Miranda, M.A., Peppelenbosch, M.P., Ferreira, C.V. and Aoyama, H. (2007). Phosphoprotein levels, MAPK activities and NFkappaB expression are affected by fisetin, J. Enzyme. Inhib. Med. Chem., 22 (4): 439-444. 
[39]. Sudheesh, S., Presannakumar, G., Vijayakumar, S. and Vijayalakshmi, N.R. (1997). Hypolipidemic effect of flavonoids from Solanum melongena plant food. Hum. Nutr., 51:321-330.

[40]. Tapiero, H. Ba, G.N. and Tew, K.D. (2002). Estrogen andenvironmental estrogens. Biomed. Pharmacother, 56:1-9.

[41]. Wiersema, J.H. and Leon, B. (1999). World Economic Plants: A Standard Reference. CRC

Press. p. 661.

[42]. Yamamoto, Y. and Gaynor, R.B.(2001). Therapeutic potential of inhibition of the NF-Kappa B pathway in the treatment of inflammation and cancer. J. Clin. Invest. 107(2): 135-142.

[43]. Young, V.R. and Peletti, P.L.(1990). Currrent concepts concerning indispensable amino acid needs in adults and their implication for international nutrition planning. Food Nutrition Bulletin,12: 289-300. 